\title{
Fas/CD95/Apo-I activates the acidic sphingomyelinase via Caspases
}

\author{
Brigit Brenner ${ }^{1}$, Klaus Ferlinz ${ }^{2}$, Heike Grassmé ${ }^{1}$, Michael \\ Weller $^{3}$, Ursula Koppenhoefer ${ }^{1}$, Johannes Dichgans ${ }^{3}$, \\ Konrad Sandhoff ${ }^{2}$ Florian Lang ${ }^{1}$ and Erich Gulbins ${ }^{1,4}$ \\ ${ }^{1}$ Department of Physiology, University of Tuebingen, Gmelinstrasse 5, 72076 \\ Tuebingen, Germany \\ 2 Department of Organic Chemistry and Biochemistry, University of Bonn, \\ Gerhard Domagk-Str. 1, 53121 Bonn, Germany \\ ${ }^{3}$ Department of Neurology, University of Tuebingen, 72076 Tuebingen, \\ Germany \\ ${ }^{4}$ corresponding author: Dr. Erich Gulbins, Department of Physiology, University \\ of Tuebingen, Gmelinstrasse 5, 72076 Tuebingen, Germany. \\ tel: 011-49-7071-2972196; fax: 011-49-7071-293073
}

Received 6.5.97; revised 27.6.97; accepted 30.7.97

Edited by D. Green

\begin{abstract}
Fas/CD95/Apo-I has been shown to stimulate a variety of molecules including several members of the caspase family and the acidic sphingomyelinase (Martin and Green 1995; Gulbins et al, 1995). Here, we demonstrate that Fas receptortriggered activation of the acidic sphingomyelinase, consumption of sphingomyelin, release of ceramide, and subsequent activation of JNK and p38-K are regulated by caspases. Inhibition of caspases by Ac-YVAD-chloromethylketone or transient CrmA transfection prevented stimulation of acidic sphingomyelinase, release of ceramide and activation of JNK and p38-K upon Fas-receptor crosslinking. Likewise, Fas triggered apoptosis was almost completely blocked by Ac-YVAD-chloromethylketone or CrmA mediated inhibition of caspases. The results suggest a new signalling cascade from the Fas receptor via caspases to acidic sphingomyelinase, ceramide and JNK/p38-K.
\end{abstract}

Keywords: apoptosis; T-lymphocytes; signalling; ceramide; proteolysis

Abbreviations: JNK, Jun N-terminal kinase; TNF, tumor necrosis factor; NGF, nerve growth factor; ASM, acidic sphingomyelinase; GST, glutathione $S$-transferase; $\mathrm{I}_{2}$-lodine; PAGE, polyacrylamidgel

\section{Introduction}

Apoptosis has been identified as an evolutionary conserved and fundamental active cellular mechanism occuring under a range of physiological and pathological conditions (Wyllie et al, 1980; Raff, 1992; Cohen, 1993). Programmed cell death is characterized by distinct morphological changes of the cell including nuclear condensation and fragmentation, membrane blebbing and formation of apoptotic bodies (Kerr et al,
1972). Several stimuli including the TNF-, NGF-, Fas/Apol/ CD95-receptor, reactive oxygen intermediates (ROI), ionizing radiation, ceramides, heat shock, cytotoxic drugs, infection by some viruses or bacteria or withdrawal of growth factors induce apoptosis in different cell types (Beutler and Huffel, 1994; Bose et al, 1995; Collins, 1995; Hockenberry et al, 1993; Itoh et al, 1991; Obeid et al, 1993; Oehm et al, 1992; Smith et al, 1994; Stevenson et al, 1994; Verheij et al, 1996; Xia et al, 1995).

The cellular homeostasis of the immune system is regulated by the balance between cell proliferation and programmed cell death. Apoptosis in mature lymphocytes can be induced by cellular stimulation via the Fas/Apol/ CD95-receptor (Singer and Abbas, 1994) belonging to the family of the NGF/TNF-receptors, which are important in the regulation of apoptosis, proliferation or differentiation (Smith et al, 1994; Beutler and Huffel, 1994). The major function of the Fas-receptor/Fas-ligand system seems to be the regulation of the peripheral immune response (Singer and Abbas, 1994; Nagata and Suda, 1995). Thus, mutations of the Fas receptor or its ligand result in the defects of Ipr and gld mice, respectively, characterized by lymphadenopathy, lymphoaccumulation and autoimmune organ failure (Watanabe-Fukunaga et al, 1992; Takahash et al, 1994; Wu et al, 1994).

Several components of the death machinery have been identified. In particular, proteases of the caspase-family have been shown to be important in Fas-triggered apoptosis (Los et al, 1995; Enari et al, 1995). Recently, it was demonstrated that the Fas receptor associates via its death domain, which exhibits significant homology with an intracellular domain of the TNF receptor and is required for induction of apoptosis (Tartaglia et al, 1993), with FADD, TRADD or RIP (Chinnaiyan et al, 1995; Hsu et al, 1995; Stanger et al, 1995). FADD in turn binds to caspase 8 (FLICE/MACH-1) (Boldin et al, 1996; Muzio et al, 1996). Caspase 8 contains an ICE/Ced-3-like protease domain which seems to be activated upon ligation and trimerization of Fas by a conformational change of caspase 8 (Boldin et al, 1996; Muzio et al, 1996). Caspase 8 then transmits the activation signal to other caspases, finally triggering cell death (Boldin et al, 1996; Muzio et al, 1996). We and others have previously demonstrated that acidic sphingomyelinases and ceramide also play an important role for Fas induced apoptosis (Cifone et al, 1994; Tepper et al, 1995; Gulbins et al, 1995). Ceramides are known stimuli of apoptosis and are released by activation of an acidic and/or neutral sphingomyelinase (Hannun, 1996). Both enzymes have been shown to be activated by the Fas receptor (Cifone et al, 1995; Tepper et al, 1995; Gulbins et al, 1995). The regulatory mechanisms of sphingomyelinase activation by the Fas receptor are completely unknown; however, recent data suggest that reaper triggered release of ceramide depends on the function of caspases (Pronk et 
al, 1996), implying that sphingomyelinases and ceramide are downstream targets of caspases. Ceramide has been shown to stimulate a variety of enzymes including a phosphatase (Joseph et al, 1993), a ceramide activated proline-directed protein kinase (Dobrowsky et al, 1993), Jun-N-terminal kinase (Verheij et al, 1996; Westwick et al, 1995), Raf-K (Huwiler et al, 1996) and tyrosine phosphorylation (Ji et al, 1995).

Several other molecules have been shown to be involved in Fas-triggered apoptosis, in particular the small G-protein p21 Ras and inhibition of Ras blocks Fas-induced programmed cell death in Jurkat $\mathrm{T}$ cells (Gulbins et al, 1995). Further molecules regulated upon Fas receptor triggering include phospholipase $A_{2}$ (Cifone et al, 1995), $\mathrm{NF} \kappa \mathrm{B}$ (Ponton et al, 1996), Jun-N-terminal Kinases (Latinis and Koretzky, 1996), tyrosine and serine/threonine-kinases (Eischen et al, 1994; Schlottmann et al, 1996; Tian et al, 1995), the tyrosine phosphatase FAP (Sato et al, 1995), Rac-proteins (Gulbins et al, 1996) or the $\mathrm{K}_{\mathrm{v}} 1.3$ potassiumchannel (Szabo et al, 1996).

To gain some insight into the molecular mechanisms of regulation of acidic sphingomyelinase, we investigated the effect of a pharmacological or CrmA mediated inhibition of caspases on acidic sphingomyelinase stimulation by Fas. The data provide evidence for a regulation of the acidic sphingomyelinase, consumption of sphingomyelin, release of ceramide and finally JNK/p38-K-activity by caspases, pointing to a novel signalling cascade important for Fasinduced apoptosis.

\section{Results}

Several results suggest a crucial function of caspases and the acidic sphingomyelinase releasing ceramide in apoptosis (Cifone et al, 1994; Gulbins et al, 1995; Tepper et al, 1995; Pronk et al, 1996). The transient and early activation of some caspases by the Fas receptor as well as the involvement of caspases in reaper-mediated ceramide release points to a possible signalling function of caspases (Los et al, 1995; Enari et al, 1995; Pronk et al, 1996) in addition to being executors of cell death.

To test the hypothesis that caspases are involved in the regulation of ceramide release via stimulation of acidic sphingomyelinase, we used two inhibitors of caspases. The pharmacological peptide Ac-YVAD-chloromethylketone inhibits predominantly caspase-1 (Darmon et al, 1996). Second, we transiently transfected a serpin like inhibitor of caspases, the viral gene CrmA, together with the B-cell surface antigen CD20 and sorted transfected cells via CD20. Similar to the pharmacological inhibitor, CrmA predominantly inactivates caspase-1, but at higher concentrations also caspase-3 (Nicholson et al, 1995; Tewari et al, 1995).

Treatment of Jurkat $T$ cells with Ac-YVAD-chloromethylketone or CrmA prevented Fas induced cell death, showing the efficiency of caspase inhibition (Figure 1). Next, we determined the consumption of sphingomyelin upon Fas receptor ligation in cells treated with Ac-YVAD-chloromethylketone, transfected with CrmA, or left untreated. The results show that pharmacological or CrmA mediated inhibition of caspases almost completely prevents sphingomyelin consumption after Fas receptor triggering in untreated cells (Figure 2a). In addition, we directly inhibited acidic sphingomyelinase using the drug imipramine $(40 \mu \mathrm{M})$. Imipramine induces degradation of the active $72 \mathrm{kDa}$ isoform of the ASM by an unknown mechanism, whereas the inactive $75 \mathrm{kDa}$ proform of the ASM is not affected by this drug (Hurwitz et al, 1994). Efficient downregulation of the ASM upon incubation with imipramine was demonstrated by Western blotting of ASM immunoprecipitates from imipraminetreated or untreated Jurkat $\mathrm{T}$ cells (Figure 2b). Shorter incubation with (less than $30 \mathrm{~min}$ ) or lower doses (10 or $20 \mu \mathrm{M})$ of imipramine resulted in a partial reduction of acidic sphingomyelinase expression correlating with a partial inhibition of acidic sphingomyelinase activity and cell death (not shown).

Imipramine treated resulted in an almost complete abrogation of sphingomyelin consumption upon Fas ligation (Figure 2a). In accordance with the inhibition of sphingomyelin consumption, transfection with CrmA or treatment of the Jurkat cells with Ac-YVAD-chloromethylketone prevented the release of ceramide detected in normal, untreated Jurkat cells upon Fas receptor stimulation (Figure $3 a$ and $b$ ). Ceramide release was also greatly reduced by preincubation of the cells with imipramine which directly blocks acidic sphingomyelinase (Figure $3 a$ and b).

Inhibition of sphingomyelin consumption and ceramide release by pharmacological or CrmA mediated blockade of caspases correlated with an almost complete prevention of Fas induced acidic sphingomyelinase activation (Figure

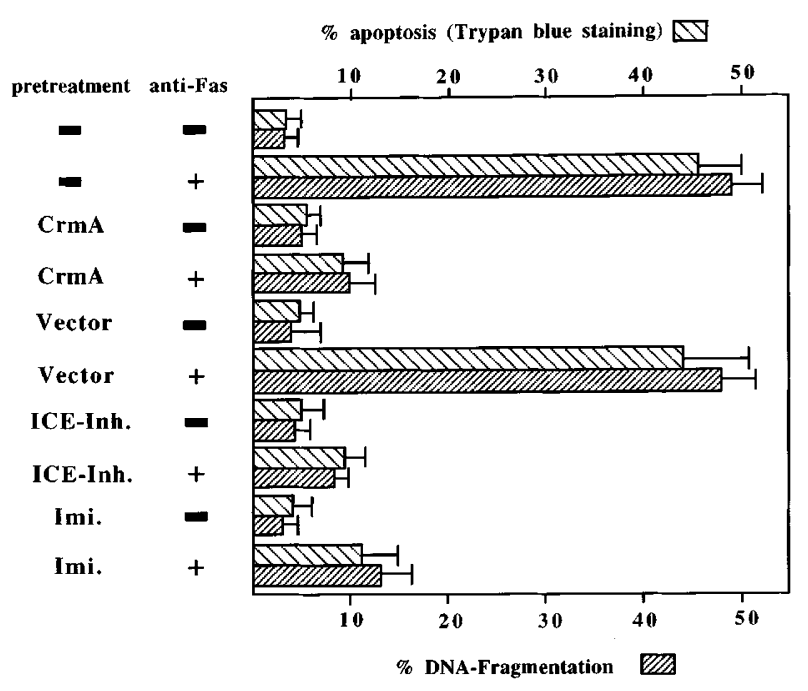

Figure 1 Fas induced cell death is inhibited by transient transfection of CrmA or pharmacological inhibition of caspases. Jurkat cells were transiently transfected with CrmA or a control vector, labeled with $\left[{ }^{3} \mathrm{H}\right]$ thymidine and stimulated via Fas. Alternatively, labeled cells were treated with $10 \mu \mathrm{M} \mathrm{Ac-}$ YVAD-chloromethylketone for $60 \mathrm{~min}$ prior to stimulation with anti-Fas. After $3 \mathrm{~h}$ incubation, cells were collected and DNA fragmentation determined by filtration through glass fiber filters and liquid scintillation counting. An aliquot of the cells was trypan blue stained and analyzed for typical morphological changes of apoptosis (Imi. = imipramine, ICE-Inh. =ICE-inhibitor, vector $=$ vector control). Experiments were done in triplicate and repeated three times 
a

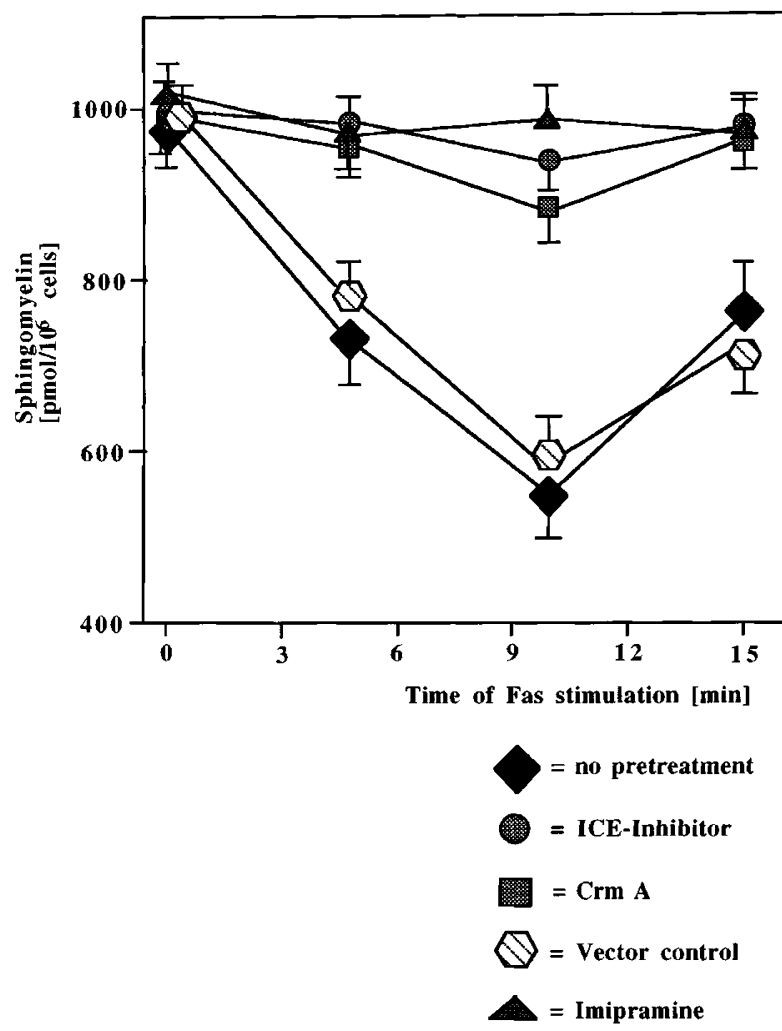

b

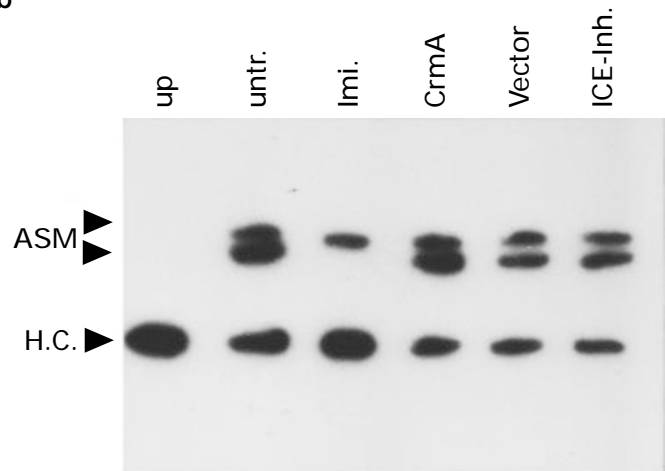

Figure 2 (a) Genetic or pharmacological inhibition of caspases prevents Fas induced sphingomyelin consumption. Similar, imipramine-induced acidic sphingomyelinase degradation blocks. Fas-triggered sphingomyelin hydrolysis. Jurkat $\mathrm{T}$ lymphocytes were transiently transfected with CrmA or vector control and an expression vector for CD20. Transfected or untransfected cells were labeled for $12 \mathrm{~h}$ with $\left[{ }^{3} \mathrm{H}\right]$ choline chloride, pretreated for 60 min with AcYVAD-chloromethylketone $(10 \mu \mathrm{M})$ or imipramine $(40 \mu \mathrm{M})$ or left untreated and stimulated via Fas. Cells were extracted organically and the extracts separated by TLC. Sphingomyelin spots were identified by comigration with sphingomyelin standards upon incubation of the TLC plates in $\mathrm{I}_{2}$-vapor. Spots were scraped from the plates and analyzed by liquid scintillation counting. Data are expressed as mean \pm s.d. of three independent experiments. (b) shows the reduction of acidic sphingomyelinase expression induced by imipramine. Acidic sphingomyelinase was immunoprecipitated from untreated (untr.) imipramine- or Ac-YVAD-chloromethylketone-treated and CrmA- or control-transfected cells. Immunoprecipitates were separated by $10 \%$ SDS-PAGE, blotted, incubated with a polyclonal anti-acidic sphingomyelinase antiserum and developed with horseradish-coupled protein G and ECL. Unspecific immunoprecipitates (up) were performed with an irrelevant goat antiserum. (H.C.=heavy chain of the anti-acidic sphingomyelinase-antibody used for immunoprecipitation)

4a), whereas untreated cells responded to anti-Fas with an approximately threefold stimulation of acidic sphingomyelinase activity. Acidic sphingomyelinase activity was directly measured by immunoprecipitation of acidic sphingomyelinase from stimulated or unstimulated cells and subsequent enzyme assay. Cells were either pretreated with the peptide Ac-YVAD-chloromethylketone blocking caspases or transfected with $\mathrm{CrmA} 36 \mathrm{~h}$ prior to the assay. Imipramine reduced acidic sphingomyelinase activity (Figure 4) and protein levels by approximately 95\% (Figure 2b), however, the remaining $5 \%$ of acidic sphingomyelinase responded normally with a threefold stimulation of acidic sphingomyelinase activity. To further confirm that treatment of the cells with imipramine does not render the cells unresponsive to Fas-receptor ligation we determined the release of DAG upon Fas receptor ligation, which has been shown to be activated independently of the ASM after TNF receptor ligation (Schütze et al, 1992). The results (Figure $4 b$ ) demonstrating a significant increase of
DAG-release after Fas show that treatment of Jurkat cells with imipramine does not induce a general signalling block. This is also indicated by the finding that addition of $10 \mu \mathrm{M}$ C6-ceramide to imipramine treated cells induced a similar rate of apoptosis as observed in cells not treated with imipramine $(51 \pm 4 \%$ after $4 \mathrm{~h}$ in imipramine treated vs $53 \pm 6 \%$ in untreated cells).

A similar inhibition of Fas induced cell death and activation of the acidic sphingomyelinase was detected after incubation of Jurkat cells with $50 \mu \mathrm{M}$ ZVAD-fmk (not shown) further supporting the notion of acidic sphingomyelinase regulation by caspases. The release of ceramide has been previously linked to the activation of JNK upon stimulation of cells via the Fas- or TNF-receptor or treatment with X-ray, UV-light or heat shock (Verheij et al, 1996). We, therefore, tested, whether caspases are involved in the activation of JNK or p38-K by Fas (Figure $5)$. JNK or p38-K activity was determined by incorporation of ${ }^{32} \mathrm{P}_{\mathrm{i}}$ in the substrate GST-C-Jun or GST-ATF-2, 
respectively. Figure 5 shows that the approximately tenfold activation of JNK or p38-K triggered by Fas is almost completely prevented by inhibition of caspases after pretreatment with Ac-YVAD-chloromethylketone or transfection of CrmA. Further, pretreatment of Jurkat cells with imipramine abolished the activation of JNK and p38-K by the Fas-receptor. The data point to a signalling cascade from Fas via caspases to ASM, ceramide and finally JNK/ p38-K activation (Figure 6).

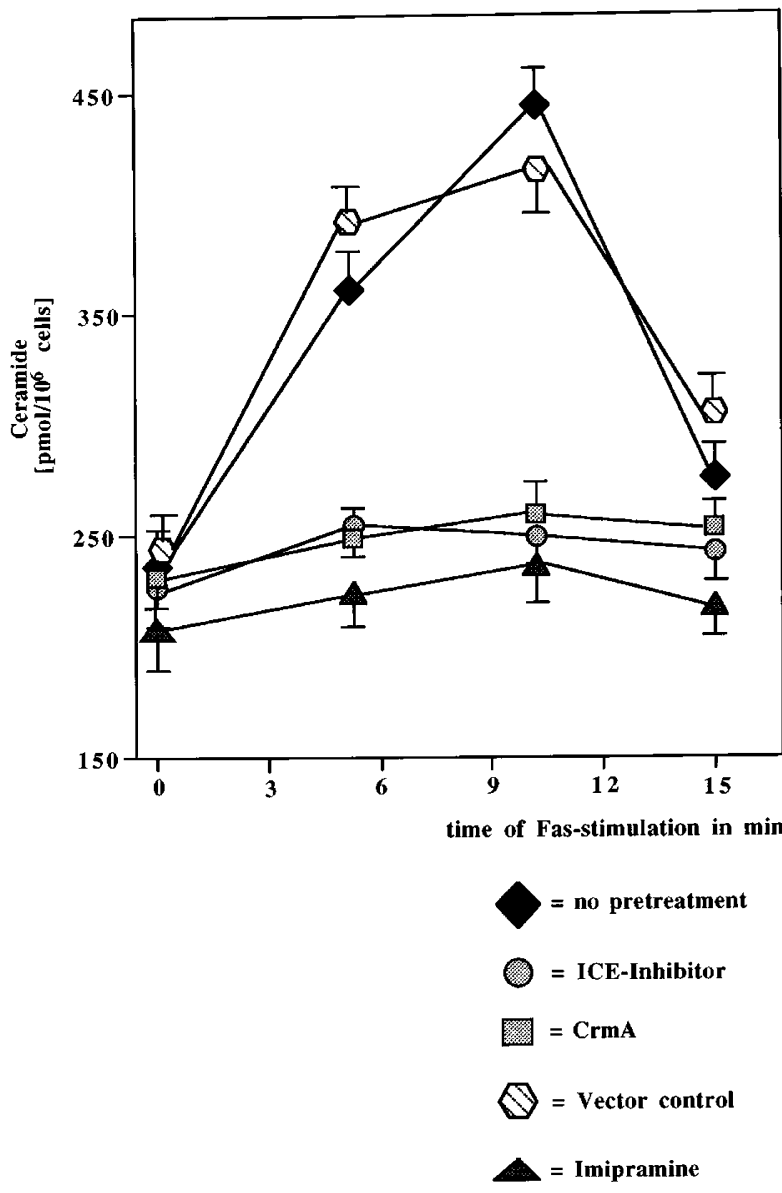

b

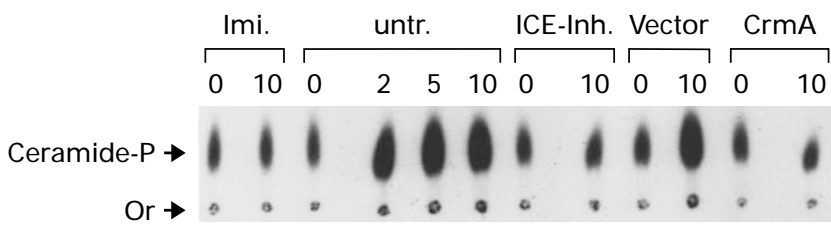

Figure 3 Ceramide release upon Fas receptor ligation is inhibited by genetic or pharmacological inhibition of caspases or acidic sphingomyelinase. CrmA or control transfected, Ac-YVAD-chloromethylketone- or imipramine-treated cells were stimulated with anti-Fas $(2 \mu \mathrm{g} / \mathrm{ml})$ for the indicated time or left untreated. Cells were extracted, incubated with a ceramide-sensitive kinase in the presence of $\left[{ }^{32} \mathrm{P}\right] \gamma$ ATP. Samples were again extracted organically, dried, separated by TLC (silica G60) and analyzed by autoradiography and liquid scintillation counting. Shown is the mean \pm s.d. of three independent results (a) and a representative autoradiography (b)

\section{Discussion}

In the present study we provide evidence for a new signalling pathway from Fas via caspases to the activation of acidic

a

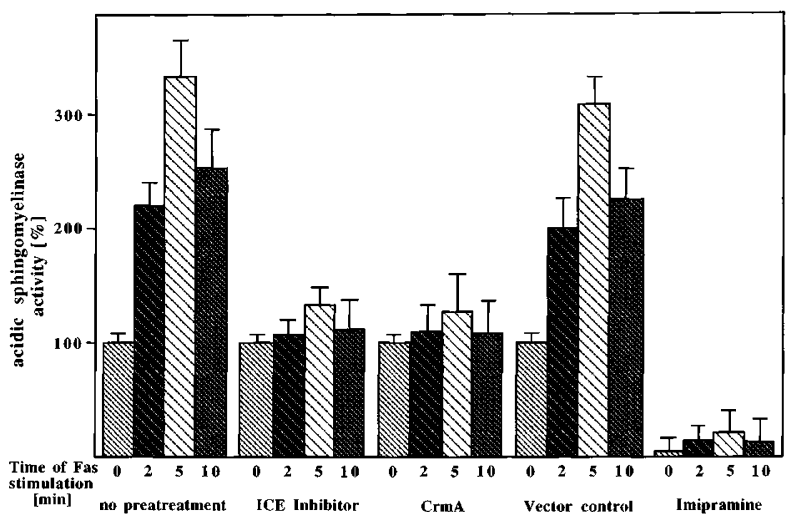

b

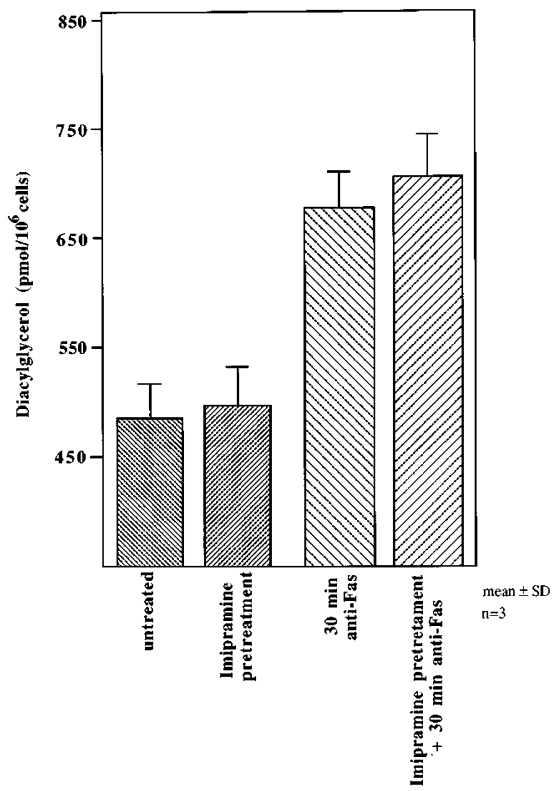

Figure 4 (a) Activation of acidic sphingomyelinase by Fas is regulated by caspases. Genetic or pharmacological inhibition of caspases prevents Fas mediated acidic sphingomyelinase stimulation. The direct acidic sphingomyelinase inhibitor imipramine reduces the absolute values of acidic sphingomyelinase activity by approximately $95 \%$. Acidic sphingomyelinase was immunoprecipitated from Fas-stimulated or unstimulated Jurkat cells transiently transfected with $\mathrm{CrmA}$ or vector control or treated with Ac-YVADchloro-methylketone or imipramine, respectively. Acidic sphingomyelinase immunoprecipitates were incubated with $\left[{ }^{14} \mathrm{C}\right]$ sphingomyelin for $30 \mathrm{~min}$ and the degradation of $\left[{ }^{14} \mathrm{C}\right]$ sphingomyelin was determined by liquid scintillation counting after organic extraction of the samples. Shown are changes of acidic sphingomyelinase activity compared to the value from unstimulated and untreated cells. Given are the mean \pm s.d. from three independent experiments. (b) Imipramine treatment does not inhibit the release of DAG upon Fas receptor ligation. Imipramine treated or untreated cells were stimulated for $30 \mathrm{~min}$ via Fas as described above, DAG was extracted from the lysates and samples were incubated with a DAG sensitive bacterial kinase in the presence of $\left[{ }^{32} \mathrm{P}\right] \gamma$ ATP. Samples were dried, resuspended, separated by TLC and analyzed by autoradiography followed by liquid scintillation counting of the corresponding spots 


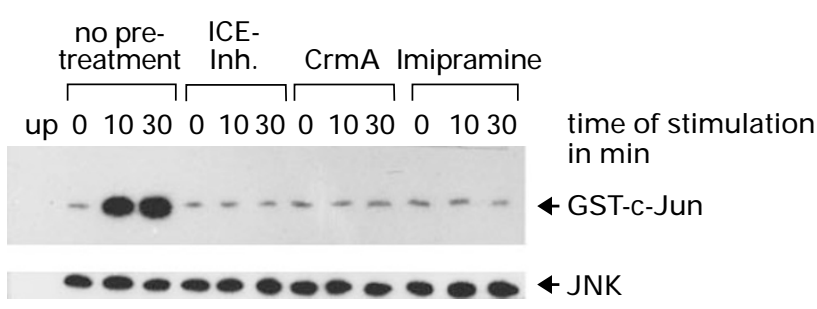

b

$$
\begin{gathered}
\text { no pre- } \\
\text { treatment }
\end{gathered} \text { Inh. }
$$

up $01030 \quad 0103001030 \quad 0 \quad 1030$

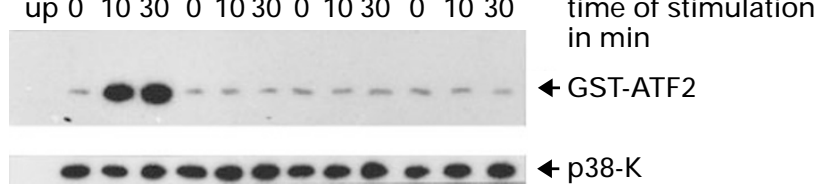

Figure 5 Inhibition of caspases or the acidic sphingomyelinase by genetic or pharmacological techniques prevents the activation of JNK (a) or p38-K (b) by Fas-receptor ligation. CrmA transfected, Ac-YVAD-chloromethylketone or imipramine treated cells were stimulated via Fas, lysed and JNK or p38-K were immunoprecipitated from the lysates using polyclonal rabbit anti-JNK or antip38-K antibodies. Immunoprecipitates were incubated for $15 \mathrm{~min}$ with [22 P] ATP $(10 \mu \mathrm{Ci} /$ sample) and GST-C-Jun or GST-ATF-2, samples were separated by SDS-PAGE, blotted and analyzed by autoradiography. Unspecific immunoprecipitates (up) were performed from anti-Fas stimulated (10 min) cells using an irrelevant, affinity purified rabbit antibody. An aliquot of the immunoprecipitates was blotted with anti-JNK or anti-p38-K to analyze protein levels in all lanes (small blots). Shown are representative autoradiographies of three independent experiments each

sphingomyelinase and the formation of ceramide. Using genetic and pharmacological inhibition of caspases we show that caspases are upstream regulators of the acidic sphingomyelinase linking the Fas receptor to the release of ceramide.

Acidic sphingomyelinase is synthesized in the cells as an inactive $75 \mathrm{kDa}$ isoform which is then processed to the active $72 \mathrm{kDa}$ isoform (Hurwitz et al, 1994; Lansmann et al, 1996). The molecular details of this processing step are unknown. It is tempting to speculate that caspase-1 or other caspases cleave acidic sphingomyelinase and thus activate the enzyme. However, this hypothesis seems to be unlikely since known caspases are cytosolic whereas acidic sphingomyelinase resides in the endosomal/lysosomal compartiment. Therefore, an indirect mechanism involving further enzymes between caspases and acidic sphingomyelinase mediating the activation of acidic sphingomyelinase is more likely. Since proteins are usually unable to cross the lipid bilayer separating caspases and acidic sphingomyelinase, it seems possible that further lipid metabolites, which readily flip from one to the other compartiment, are released in the cytosol upon Fas receptor ligation and mediate the activation of the acidic sphingomyelinase.

CrmA and Ac-YVAD-chloromethylketone have been previously shown to inhibit members of the caspase family and to prevent Fas-induced apoptosis (Smith et al, 1996; Tewari and Dixit, 1995) pointing to the significance of this

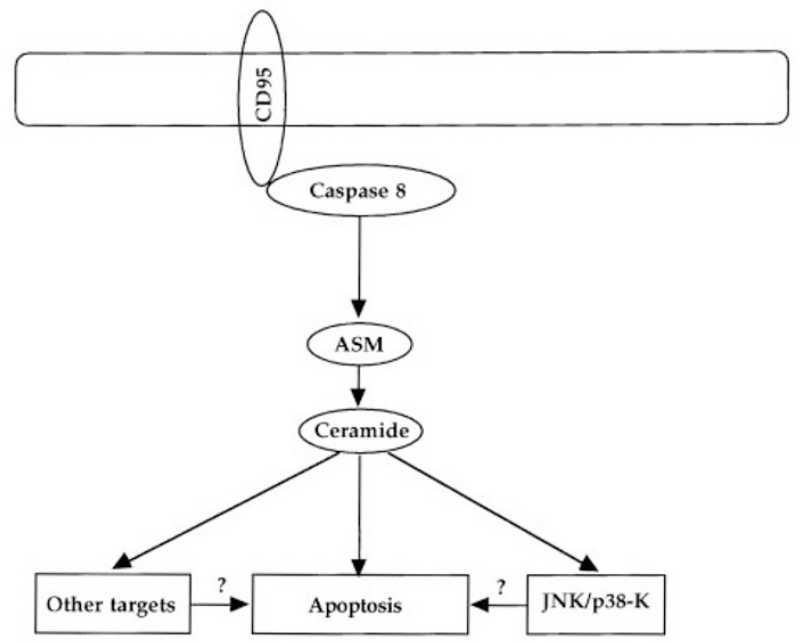

Figure 6 Model of Fas regulated activation of acidic sphingomyelinase by caspases. Fas may stimulate several members of the caspases family including caspase 8 , which then directly or indirectly stimulate the acidic sphingomyelinase. Ceramide released by acidic sphingomyelinse activity may stimulate other members of the caspase family, JNK/p38-K or other molecules involved in Fas receptor signalling

signalling pathway for Fas mediated apoptosis. CrmA predominantly inhibits caspase- 1 and -8 , however, at very high concentrations it also binds to and inhibits caspase- 3 (Nicholson et al, 1995; Tewari et al, 1995; Salvesen et al, 1997). Similar to CrmA, the pharmacological inhibitor AcYVAD-chloromethylketone inhibits predominantly caspase1, whereas several other caspases are almost unaffected by this peptide (Darmon et al, 1996). Since caspase-8 seems to be one of the primary cellular targets of CrmA under physiological conditions (Zhou et al, 1997) and plays a major role in Fas triggered cell death (Boldin et al, 1996; Muzio et al, 1996), this caspase is a good candidate for the protease involved in the regulation of acidic sphingomyelinase activation by Fas. However, the exact nature of the caspase involved in acidic sphingomyelinase activation has to be elucidated.

Our data suggest that caspase-1 itself or enzymes closely related to caspase-1 are (indirectly) mediating the activation of acidic sphingomyelinase upon Fas receptor ligation. It is unknown whether caspases are only executors of apoptosis or whether they also function as signalling molecules, however, our data indicate a signalling function of at least some caspases rather than being just executors of apoptosis. This notion is supported by several other studies: First, expression of the reaper protein, which is homologous to the cytoplasmic domain of Fas or TNF results in activation of caspases as well as in the formation of ceramide (Pronk et al, 1996). Inhibition of caspases prevents reaper triggered ceramide release placing ceramide downstream of caspases (Pronk et al, 1996). Ceramide, however, stimulates via a Bcl2 sensitive pathway other members of the caspase family, in particular caspase-3 (Smyth et al, 1996; Zhang et al, 1996). Thus, 
ceramide seems to be an intermediate in the death cascade between several caspases. Second, expression of CrmA in transgenic mice prevents Fas-induced apoptosis (Smith et al, 1996). However, these lymphocytes are still susceptible to $\mathrm{X}$-irradiation induced apoptosis. Since $\mathrm{X}$-rays induce an increase of ceramide concentration (Haimovitz-Friedman et al, 1994), the results of these transgenic animals suggest that ceramide functions downstream of at least some caspases to mediate cell death. Third, it has been recently shown, that CrmA-, YVAD-cmk- or Z-VAD-fmk-mediated inhibition of caspases prevents Fas triggered p38-K activation (Juo et al, 1997) directly supporting the data of the present study. Further, Fas-receptor ligation has been shown to induce only a transient activation of caspases, peaking approximately already $20 \mathrm{~min}$ after stimulation via the Fas receptor (Los et al, 1995; Enari et al, 1995). Thus, some caspases seem to be very early signalling molecules activated by the Fas receptor and might be upstream of the acidic sphingomyelinase. Finally, the release of ceramide upon ligation of the TNF receptor belonging to the same receptor family as Fas is inhibited by transfection of CrmA (Dbaibo et al, 1997). This also suggests that some CrmA sensitive caspases are involved in the regulation of a sphingomyelinase.

Our notion of an activation of JNK and $\mathrm{p} 38-\mathrm{K}$ by Fas receptor ligation via stimulation of the acidic sphingomyelinase is supported by previous studies showing that Fas or ceramides stimulate JNK/p38-K (Verheij et al, 1996; Westwick et al, 1995; Latinis et al, 1996; Juo et al, 1997; Lenczowski et al, 1997). Furthermore, ceramide-initiated JNK activation has been demonstrated to be essential for the induction of apoptosis after ionizing radiation, UV-light, heat shock, TNF $\alpha$ or $\mathrm{H}_{2} \mathrm{O}_{2}$ (Verheij et al, 1996), suggesting an important function of ceramide triggered activation of JNK for ceramide mediated programmed cell death. Fas belongs to a family of receptors including TNF, p75-NGF, OX-40, CD40 and some further molecules (Beutler and Huffel, 1994; Smith et al, 1994). Apoptosis induced by p75-NGF receptor has been shown to involve activation of $\mathrm{JNK} / \mathrm{p} 38-\mathrm{K}$ and inhibition of $\mathrm{JNK} / \mathrm{p} 38-\mathrm{K}$ prevented cell death induced by NGF withdrawal from PC12-pheochromocytoma cells (Xia et al, 1995). The activation of a similar signal transduction pathway has been reported to be stimulated by the TNF receptor (Verheij et al, 1996; Schütze et al, 1992; Trent et al, 1996). These studies show a release of ceramide and an activation of Ras and JNK/p38-K after TNF receptor ligation which are critically involved in TNF-receptor mediated cell death (Verheij et al, 1996; Schütze et al, 1992; Trent et al, 1996). Thus, TNF, p75-NGF and Fas seem to activate similar molecular mechanisms upon induction of apoptosis. However, a recent study using transfection of FADD, RIP or TRAF-2 into MCF-7 cells proposed that JNK-activation and apoptosis after TNF-receptor ligation are separate responses (Liu et al, 1996). Therefore, JNK-activation may not be sufficient to trigger apoptosis by itself, however, under physiological conditions it might be necessary as a positive signal for other signals triggering programmed cell death. In situations with very high activation levels of the pathway triggering apoptosis, e.g. after transfection of genes inducing cell death, this positive feedback may not be absolutely required.

The results of the present study using imipramine point to an involvement of the acidic sphingomyelinase in Fas triggered death. However, since imipramine probably does not specifically inhibit the acidic sphingomyelinase, the exact function of this enzyme in Fas triggered cell death has to be elucidated using genetic approaches.

Taken together, the data suggest the following model: Fas activates some caspases (caspase 8 is a good candidate) which then stimulate directly or indirectly the acidic sphingomyelinase resulting in the release of ceramide. The activation of acidic sphingomyelinase and the release of ceramide seem to be crucial for Fas induced apoptosis since acidic sphingomyelinase deficient lymphocytes are resistant to Fas induced apoptosis (R. Kolesnick, personal communication). Ceramide may have multiple functions including the activation of $\mathrm{JNK} / \mathrm{p} 38-\mathrm{K}$ as well as the stimulation of further members of the caspase family, e.g. caspase-3. These molecules then execute the apoptotic signal delivered by cellular stimulation via the Fas receptor (Figure 6).

\section{Materials and Methods}

\section{Cell culture and stimulation}

All reagents were purchased from Sigma, Deisenhofen, Germany, if not otherwise cited. Human Jurkat T cells were grown in RPMI-1640 medium supplemented with $10 \%$ fetal calf serum, $10 \mathrm{mM}$ HEPES (pH 7.4), $2 \mathrm{mM}$ L-glutamine, $1 \mathrm{mM}$ sodium pyruvate, $100 \mu \mathrm{M}$ non essential amino acids, 100 units $/ \mathrm{ml}$ penicillin, $100 \mu \mathrm{g} / \mathrm{ml}$ streptomycin and $50 \mu \mathrm{M} \beta$-mercaptoethanol (all from Gibco-BRL, Eggenstein, Germany). For activation, cells were washed twice in HEPES buffered saline $(\mathrm{H} / \mathrm{S}, 132 \mathrm{mM} \mathrm{NaCl}, 20 \mathrm{mM}$ HEPES, $5 \mathrm{mM} \mathrm{KCl}$, $1 \mathrm{mM} \mathrm{CaCl}_{2}, 0.7 \mathrm{mM} \mathrm{MgCl}_{2}, 0.8 \mathrm{mM} \mathrm{MgSO}_{4}$ ) and incubated at $37^{\circ} \mathrm{C}$ with $2 \mu \mathrm{g} / \mathrm{ml}$ monoclonal anti-human-Fas-antibody (clone $\mathrm{CH}-11$; Dianova-Immunotech, Hamburg, Germany) for the indicated times.

\section{Inhibition of caspases and acidic sphingomyelinase}

Co-transfection of Jurkat cells with $40 \mu \mathrm{g}$ each SRS $\alpha$-crmA or vector control (SRS $\alpha$ ) with an expression vector for CD20 (pRc/CMV-cd20) $(10 \mu \mathrm{g})$ was performed as previously described (10). Briefly, cells were electroporated using a BTX-electroporator at five pulses $(99 \mu \mathrm{sec})$ and $500 \mathrm{~V}$. Twelve hours later viable cells were purified by Ficoll gradient centrifugation and cultured for an additional $24 \mathrm{~h}$. CD20 ${ }^{+}$cells were then selected by incubation with $50 \mu \mathrm{g} / \mathrm{ml}$ anti-CD20 mAb (Dianova) (60 $\mathrm{min}, 4^{\circ} \mathrm{C}$ ), three times washing and further incubation $(60 \mathrm{~min}$, $4^{\circ} \mathrm{C}$ ) with magnetic beads coated with a sheep anti-mouse Immunoglobulin (Dynal, Hamburg, Germany) (Gulbins et al, 1995). Since the ratio of $5: 1 \mathrm{SRS} \alpha-\mathrm{crmA}: \mathrm{pRc} / \mathrm{CMV}$-cd20 drives expression of $\mathrm{CrmA}$ in any $\mathrm{CD} 2 \mathrm{O}^{+}$cell, the selection of $\mathrm{CD} 2 \mathrm{O}^{+}$cells permits effective sorting for CrmA expressing cells. The fraction of CD20positive and thus CrmA transfected cells was determined by in vivo labeling of the cells with $\left[{ }^{3} \mathrm{H}\right]$ thymidine as previously described (Gulbins et al, 1995). Aliquots of labeled cells were counted prior and after sorting via magnetic beads. These experiments showed that approximately $10 \%$ of all cells were CD20-positive. Non-specific binding of the cells to the magnetic beads did not excede $0.5 \%$ of all 
cells as determined by incubation of cells with an irrelevant monoclonal mouse antibody $(50 \mu \mathrm{g})$ and magnetic beads. Purified cells were allowed to recover for $30 \mathrm{~min}$ at $37^{\circ} \mathrm{C}$ and then used for biological assays or determination of apoptosis.

Alternatively, caspases were inhibited by 60 min preincubation with $10 \mu \mathrm{M}$ of the irreversible pharmacological inhibitor Ac-YVADchloromethylketone (Bachem, Hannover, Germany). Acidic sphingomyelinase was inhibited by $60 \mathrm{~min}$ preincubation of the cells with $40 \mu \mathrm{M}$ imipramine in RPMl $/ 1640$ supplemented with $0.5 \%$ BSA, $10 \mathrm{mM}$ HEPES ( $\mathrm{pH}$ 7.4), $2 \mathrm{mM}$ L-glutamine, $1 \mathrm{mM}$ sodium pyruvate and $100 \mu \mathrm{M}$ non essential amino acids.

\section{Measurement of sphingomyelin consumption}

Cells were metabolically labeled by incubation with $1 \mu \mathrm{Ci} / \mathrm{ml}$ [methyl- ${ }^{3} \mathrm{H}$ ]choline chloride $(60-90 \mathrm{Ci} / \mathrm{mmol}$; NEN-DuPont, BadHomburg, Germany) for $48 \mathrm{~h}$ in complete RPMI-medium. Cells were washed three times and stimulated via Fas for the indicated time. Infection was terminated by extraction in $120 \mu \mathrm{l} 0.22 \mathrm{M} \mathrm{HCl}, 2.7 \mathrm{ml}$ $\mathrm{CHCl}_{3}: \mathrm{CH}_{3} \mathrm{OH}(2: 1, \mathrm{v} / \mathrm{v}), 0.9 \mathrm{ml}$ of $\mathrm{CHCl}_{3}$ and $0.9 \mathrm{ml}$ of $1 \mathrm{M} \mathrm{KCl}$. The organic phase was collected after mixing and centrifugation for $15 \mathrm{~min}$ at $800 \times \mathrm{g}$, dried, resuspended in $\mathrm{CHCl}_{3}: \mathrm{CH}_{3} \mathrm{OH}(1: 1, \mathrm{v} / \mathrm{v})$ and lipids were separated on $\mathrm{G} 60$ silica gel thin layer chromatography plates (MacheryNagel, Dueren, Germany) using $\mathrm{CHCl}_{3}: \mathrm{CH}_{3} \mathrm{OH}: \mathrm{H}_{2} \mathrm{O}$ : acetic acid $(50: 30: 8: 4, \mathrm{v} / \mathrm{v} / \mathrm{v} / \mathrm{v})$ as solvent system. Sphingomyelin was identified by co-migration with standards, scrapped from the plate and radioactivity in each spot determined by liquid scintillation counting.

\section{Activity of acidic sphingomyelinase}

The activity of acidic sphingomyelinase upon Fas receptor ligation was measured by an immunoprecipitation technique. Stimulated or unstimulated cells were lysed in ice-cold $50 \mathrm{mM}$ Tris $(\mathrm{pH} 7.4)$, $10 \mathrm{mM}$ Bacitracin, $1 \mathrm{mM}$ Benzamidine, $10 \mathrm{mM} \mathrm{Na}_{3} \mathrm{VO}_{4}, 10 \mu \mathrm{g} / \mathrm{ml}$ of each aprotinin and leupeptin, $0.1 \mathrm{mg} / \mathrm{ml}$ soybean trypsin inhibitor and $0.2 \%$ Triton X-100 and immediately sonicated for $10 \mathrm{~s}$. Sonication was repeated three times and insoluble cell debris pelleted by $5 \mathrm{~min}$ centrifugation at $600 \times \mathrm{g}$. An equal amount of $50 \mathrm{mM}$ Tris $(\mathrm{pH} 7.4), 3 \%$ NP40, $1 \%$ Triton X-100, $10 \mathrm{mM} \mathrm{Na}_{3} \mathrm{VO}_{4}, 100 \mu \mathrm{g} / \mathrm{ml}$ each aprotinin and leupeptin (lysis buffer) was added to the samples and ASM was immunoprecipitated from the supernatants using a goat anti-ASMantiserum previously characterised (Hurwitz et al, 1994). Samples were incubated for $4 \mathrm{~h}$ at $4{ }^{\circ} \mathrm{C}$, immunocomplexes were immobilized by addition of $20 \mu \mathrm{l}$ protein $\mathrm{A} / \mathrm{G}$ coupled agarose (Santa Cruz Inc, Santa Cruz, CA), and further incubation for $60 \mathrm{~min}$ at $4^{\circ} \mathrm{C}$. The immunoprecipitates were washed three times in lysis buffer, followed by additional three washes in $50 \mathrm{mM}$ sodium acetate $(\mathrm{pH} \mathrm{5.0),0.2 \%}$ Triton X-100, $1 \mathrm{mM} \mathrm{Na} \mathrm{VO}_{4}$ and $10 \mu \mathrm{g} / \mathrm{ml}$ each aprotinin and leupeptin. Washed immunoprecipitates were incubated with $\left[{ }^{14} \mathrm{C}\right]$ sphingomyelin $(0.5 \mu \mathrm{Ci} /$ sample, $54.5 \mathrm{mCi} / \mathrm{mmol}$; NEN-DuPont) in $250 \mathrm{mM}$ sodium acetate (pH 5.0), $1.3 \mathrm{mM}$ EDTA, 0.05\% NP40 (assay buffer) at $37^{\circ} \mathrm{C}$ for $30 \mathrm{~min}$. The substrate $\left[{ }^{14} \mathrm{C}\right]$ sphingomyelin was solubilized after drying by $10 \mathrm{~min}$ bath sonication in assay buffer. Assays were terminated by extraction with $800 \mu \mathrm{l}$ Chloroform: Methanol $(2: 1, \mathrm{v} / \mathrm{v})$ and $250 \mu \mathrm{l} \mathrm{H}_{2} \mathrm{O}$. The upper phase was collected and radioactivity reflecting the degradation of $\left[{ }^{14} \mathrm{C}\right]$ sphingomyelin was determined by liquid scintillation counting.

\section{Determination of diacylglycerol and ceramide}

For determination of ceramide, cells were stimulated with anti-Fas antibodies for the indicated time, washed and extracted with $\mathrm{CH}_{3}: \mathrm{CH}_{3} \mathrm{OH}: \mathrm{HCl}(100: 100: 1, \mathrm{v} / \mathrm{v} / \mathrm{v})$. Aliquots of the organic phase were dried under vacuum, DAG was digested by mild alkaline hydrolysis in $0.1 \mathrm{M}$ methanolic $\mathrm{KCl}$, the samples were reextracted as above, dried and solubilized by $10 \mathrm{~min}$ bath sonication in $7.5 \%(\mathrm{w} / \mathrm{v}) \mathrm{n}$ octyl- $\beta$-glucopyranoside, $5 \mathrm{mM}$ cardiolipin, $1 \mathrm{mM}$ diethylenetriaminepentaacetic acid (DETAPAC). After sonication $40 \mu \mathrm{g} / \mathrm{ml}$ of purified $E$. coli DAG-kinase (Amersham, Braunschweig, Germany) in $70 \mu \mathrm{l}$ reaction buffer (100 mM imidazole- $\mathrm{HCl}(\mathrm{pH} 6.6), 100 \mathrm{mM} \mathrm{NaCl}$, $25 \mathrm{mM} \mathrm{MgCl} 2$ and $2 \mathrm{mM} \mathrm{EGTA}$ ) supplemented with $10 \mu \mathrm{Ci} / \mathrm{sample}$ $\left.{ }^{32} \mathrm{P}\right] \gamma \mathrm{ATP}$ and $1 \mathrm{mM}$ ATP were added and the samples were incubated at $22^{\circ} \mathrm{C}$ for $30 \mathrm{~min}$. The kinase reaction was stopped by addition of $1 \mathrm{ml} \mathrm{CHCl}_{3}: \mathrm{CH}_{3} \mathrm{OH}: \mathrm{HCl}(100: 100: 1, \mathrm{v} / \mathrm{v} / \mathrm{v}), 170 \mu$ of salt solution (10 mM HEPES (pH 7.2), $135 \mathrm{mM} \mathrm{NaCl}, 1.5 \mathrm{mM} \mathrm{CaCl}_{2}$, $0.5 \mathrm{mM} \mathrm{MgCl} 2$ and $5.6 \mathrm{mM}$ glucose) and $30 \mu \mathrm{l}$ of $100 \mathrm{mM}$ EDTA. The lower organic phase was dried, resuspended in $\mathrm{CHCl}_{3}: \mathrm{CH}_{3} \mathrm{OH}(1: 1$, $\mathrm{v} / \mathrm{v})$ and resolved by TLC using $\mathrm{CHCl}_{3}: \mathrm{CH}_{3} \mathrm{OH}$ : acetic acid $(65: 15: 5$, $\mathrm{v} / \mathrm{v} / \mathrm{v}$ ) as solvent. Spots were visualized by autoradiography, scrapped from the plate and analyzed by liquid scintillation counting. The ceramide content of the samples was determined by comparison with a standard curve containing known quantities of ceramide.

The release of DAG was determined by the same protocol with omission of the mild alkaline hydrolysis in $0.1 \mathrm{M}$ methanolic $\mathrm{KCl}$.

\section{JNK- and p38-K-activity}

To measure the activity of JNK or p38-K, cells were lysed in $25 \mathrm{mM}$ HEPES ( $\mathrm{pH} 7.4$ ), $0.2 \%$ SDS, $0.5 \%$ sodium deoxycholate, $1 \%$ Triton $\mathrm{X}$ $100,125 \mathrm{mM} \mathrm{NaCl}, 10 \mathrm{mM}$ each $\mathrm{NaF}, \mathrm{Na}_{3} \mathrm{VO}_{4}$ and sodium pyrophosphate and $10 \mu \mathrm{g} / \mathrm{ml}$ of each aprotinin and leupeptin (RIPAbuffer) after stimulation via Fas. Lysates were centrifuged at $25000 \times \mathrm{g}$ for $20 \mathrm{~min}$ and JNK or p38-K immunoprecipitated from the supernatants at $4{ }^{\circ} \mathrm{C}$ for $4 \mathrm{~h}$ using polyclonal rabbit anti-human JNK- or p38-K-antiserum (Santa Cruz Inc.). Immunocomplexes were immobilized on agarose-coupled protein $A / G$, incubated for additional 60 min at $4^{\circ} \mathrm{C}$, washed twice in RIPA-buffer, twice in $\mathrm{H} / \mathrm{S}, 1 \% \mathrm{NP}-40$, $2 \mathrm{mM} \mathrm{Na}_{3} \mathrm{VO}_{4}$, once in $100 \mathrm{mM} \mathrm{TrisHCl}(\mathrm{pH} 7.5), 0.5 \mathrm{M} \mathrm{LiCl}$ and finally twice in kinase buffer $12.5 \mathrm{mM}$ MOPS $(\mathrm{pH} 7.5), 12.5 \mathrm{mM} \beta$ glycerophosphate, $7.5 \mathrm{mM} \mathrm{MgCl}_{2}$ and $0.5 \mathrm{mM}$ of each NaF, EGTA and $\mathrm{Na}_{3} \mathrm{VO}_{4}$. After washing, the immunoprecipitates were resuspended in kinase buffer supplemented with $10 \mu \mathrm{Ci} /$ sample $\left[{ }^{32} \mathrm{P}\right] \gamma \mathrm{ATP}(6000 \mathrm{Ci} /$ mmol, NEN/DuPont), $10 \mu \mathrm{M}$ ATP and $1 \mu \mathrm{g} / \mathrm{ml}$ GST-c-Jun (aminoacids $1-79$ ) or GST-ATF-2 (aminoacids 1-96). The samples were incubated at $30^{\circ} \mathrm{C}$ for $15 \mathrm{~min}$ and stopped by addition of $5 \mu \mathrm{l}$ boiling $5 \times$ reducing SDS-sample buffer. Samples were separated by $10 \%$ SDS-PAGE and analyzed by autoradiography. The substrates GSTc-Jun or GST-ATF-2 were expressed in DH5 $\alpha$-bacteria after transformation, growth for $12 \mathrm{~h}$ and incubation with IPTG $(200 \mu \mathrm{M})$ for $4 \mathrm{~h}$. Bacteria were lysed in $25 \mathrm{mM}$ HEPES (pH 7.4), $0.2 \%$ SDS, $0.5 \%$ sodium deoxycholate, $1 \%$ Triton $\mathrm{X}-100,125 \mathrm{mM} \mathrm{NaCl}$ and $10 \mu \mathrm{g} / \mathrm{ml}$ of each aprotinin and leupeptin; GST-fusion proteins were purified by binding to glutathione agarose and eluted in kinase buffer with $20 \mathrm{mM}$ glutathione. Purity of the preparations was tested by SDS-PAGE and Coomassie staining.

\section{Apoptosis}

Fas-induced cell death was determined by metabolic labeling of CrmAtransfected or untransfected Jurkat cells for $12 \mathrm{~h}$ with $10 \mu \mathrm{Ci} / \mathrm{ml}$ $\left[{ }^{3} \mathrm{H}\right]$ thymidine (8.3 Ci/mmol; NEN/DuPont) (Gulbins et al, 1995). Cells were washed, aliquoted, pretreated with Ac-YVAD-chloromethylketone or imipramine and incubated with anti-Fas $(200 \mathrm{ng} / \mathrm{ml})$ or left untreated. Cell death was determined after $3 \mathrm{~h}$ by DNA fragmentation and trypan blue staining. Briefly, cells were disrupted by one cycle of freezing at $-20^{\circ} \mathrm{C}$ and thawing, unfragmented genomic DNA was 
collected by filtration through glass fiber filters (Pharmacia, Freiburg, Germany) and counted by liquid scintillation (Gulbins et al, 1995). Results are expressed as \% DNA fragmentation \pm s.d. compared with control samples. Experiments were done in triplicates and repeated three times. In all experiments an aliquot of the cells was analyzed for cell death by trypan blue. Apoptosis was further identified by typical morphological changes, in particular membrane blebbing, condensation and fragmentation of nuclei. Comparison of the DNA fragmentation method with morphologic changes permits exact determination of apoptosis vs necrosis. In all experiments apoptosis in untreated cells did not excede $5 \%$ of all cells.

\section{Acknowledgements}

The authors would like to thank $A$. Behyl for excellent technical help. This study was supported by DGF-grants Gu 335-2/2 and La 315-6/1, AICRgrant 94-194, the Mildred-Scheel-Stiftung (grant 10-0983), the Else Uebelmesser society and the Fortuene program of the University of Tuebingen to E.G. and M.W., a grant from the university of Heidelberg to B.B. and SFB 400 , A5 to K.S

\section{References}

Beutler B and van Huffel C (1994) Unraveling function in the TNF ligand and receptor families. Science 264: $667-668$

Boldin MP, Goncharov TM, Goltsev YV and Wallach D (1996) Involvement of MACH a novel MORT1/FADD-interacting protease, in Fas/APO-1 and TNF receptorinduced cell death. Cell 85: 803-815

Bose R, Verheij M, Haimovitz-Friedman A, Scotto K, Fuks Z and Kolesnick R (1995) Ceramide synthase mediates daunorubicin-induced apoptosis: an alternative mechanism for generating death signals. Cell 82: 405-414

Chinnaiyan AM, O'Rourke K, Tewari M and Dixit VM (1995) FADD, a novel death domain-containing protein interacts with the death domain of Fas and intiaties apoptosis. Cell 81: 505-512

Cifone MG, DeMaria R, Roncali P, Rippo MR, Azuma M, Lanier LL, Santoni A and Testi R (1994) Apoptotic signaling through CD95 (Fas/Aop-1) activates an acidic sphingomyelinase. J. Exp. Med. 180: 1547-1552

Cifone MG, Roncaioli P, de Maria R, Camarda G, Santoni A, Ruberti G and Testi R (1995) Multiple pathways originate at the Fas/APO-1 (CD95) receptor: sequential involvement of phosphatidylcholine-specific phospholipase $\mathrm{C}$ and acidic sphingomyelinase in the propagation of the apoptotic signal. Embo J. 14: $5859-5868$

Cohen JJ (1993) Apoptosis. Immunol. Today 14: 126-130

Collins M (1995) Potential role of apoptosis in viral pathogenesis. Am. J. Respir. Crit. Care Med. 152: S20-24

Darmon AJ and Bleackley RC (1996) An interleukin-1 $\beta$ converting enzyme-like protease is a key component of Fas mediated apoptosis. J. Biol. Chem. 271: 21699-21702

Dbaibo GS, Perry DK, Gamard CJ, Platt R, Poirier GG, Obeid LM and Hannun YA (1997) Cytokine response modifier A (Crm A) inhibits ceramide formation in response to tumor necrosis factor (TNF)- $\alpha$ : CrmA and Bcl-2 target distinct components in the apoptotic pathway. J. Exp. Med. 185: 481-490

Dobrowsky RT, Kamibayashi C, Mumby MC and Hannun YA (1993) Ceramide activates heterotrimeric protein phosphatase 2A. J. Biol. Chem. 268: $15523-$ 15530

Eischen CM, Dick CJ and Leibson PJ (1994) Tyrosine-kinase activation provides an early and requisite signal for Fas-induced apoptosis. J. Immunol. 153: $1947-$ 1953

Enari M, Hug H and Nagata S (1995) Involvement of an ICE-like protease in Fas mediated apoptosis. Nature 375: 78-81

Gulbins E, Bissonette R, Mahboubi A, Nishioka W, Brunner T, Baier G, BaierBitterlich G, Byrd C, Lang F, Kolesnick R, Altman A and Green D (1995) Fas induced apoptosis is mediated via a ceramide-initiated Ras signaling pathway. Immunity 2: 341-351
Gulbins E, Coggeshall KM, Brenner B, Schlottmann K, Linderkamp O and Lang F (1996) Fas-induced apoptosis is mediated by activation of a Ras and Rac proteinregulated signaling pathway. J. Biol. Chem. 271:26389-26394

Haimovitz-Friedman A, Kan CC, Ehleiter D, Persaud RS, McLoughlin M, Fuks Z and Kolesnick RN (1994) lonising radiation acts on cellular membranes to generate ceramide and initiate apoptosis. J. Exp. Med. 180: 525-535

Hannun YA (1996) Functions of ceramide in coordinating cellular responses to stress. Science 274: 1855-1859

Hockenberry DM, Oltvai ZN, Yin XM, Milliman CL and Korsmeyer SJ (1993) Bcl2 functions in an antioxidant pathway to prevent apoptosis. Cell 75: 241-251

Hsu H, Xiong J and Goeddel DV (1995) The TNF receptor 1-associated protein TRADD signals cell death and NF- $k$ B activation. Cell 81: 495-504.

Hurwitz R, Ferlinz K and Sandhoff K (1994) The tricyclic antidepressant desipramine causes proteolytic degradation of lysosomal sphingomyelinase in human fibroblasts. Biol. Chem. Hoppe Seyler 375: 447-450

Huwiler A, Brunner J, Hummel R, Vervoordelonk M, Stabel S, van den Bosch H and Pfeilschifter J (1996) Ceramide-binding and activation defines protein kinase cRaf as ceramide activated protein kinase. Proc. Natl. Acad. Sci. USA 93:6959 6993

Itoh N, Yonehara S, Ishii A, Yonehara M, Mizushima S, Sameshima M, Hase A, Seto Y and Nagata S (1991) The polypeptide encoded by the cDNA for human cell surface antigen Fas can mediate apoptosis. Cell 66: 233-243

Ji L, Zhang G and Hirabayashi Y (1995) Inhibition of tumor necrosis factor alpha- and ceramide induced internucleosomal DNA fragmentation by herbimycin A in U937 cells. Biochem. Biophys. Res. Commun. 215: 489-496

Joseph CK, Byun HS, Bittman R and Kolesnick RN (1993) Substrate recognition by ceramide-activated protein kinase. Evidence that kinase activity is prolinedirected. J. Biol. Chem. 268: 20002-20006

Juo P, Kuo CJ, Reynolds SE, Konz RF, Raingeaud J, Davis RJ, Biemann HP and Blenis $J$ (1997) Fas activation of the p38-mitogen-activated protein kinase signalling pathway requires ICE/CED-3 family proteases. Mol. Cell. Biol. 17:2435

Kerr JFR, Wyllie AH and Currie AR (1972) Apoptosis: A basic biological phenomenon with wideranging implications in tissue kinetics. Br. J. Cancer 26: 239-257

Lansmann S, Ferlinz K, Hurwitz R, Bartelsen O, Glombitza G and Sandhoff K (1996) Purification of acid sphingomyelinase from human placenta: Characterization and N-terminal sequence. FEBS-Letters 399: 227-231

Latinis KM and Koretzky GA (1996) Fas ligation induces apoptosis and Jun kinase activation independently of CD45 and Lck in human T cells. Blood 87: 871-875

Lenczowski JM, Dominguez L, Eder AM, King LB, Zacharchuk CM and Ashwell JD (1997) Lack of a role for Jun kinase and AP-1 in Fas-induced apoptosis. Mol. Cell. Biol. 17: 170-181

Liu ZG, Hsu H, Goeddel DV and Karin M (1996) Dissection of TNF receptor 1 effector functions: JNK activation is not linked to apoptosis while $\mathrm{NF}_{\kappa} \mathrm{B}$ activation prevents cell death. Cell: $87: 566-576$

Los M, van de Craen M, Penning LC, Schenk H, Westendorp M, Baeuerle PA, Dröge W, Krammer PH, Fiers W and Schultze-Osthoff K (1995) Requirement of an ICE/ Ced-3 protease for Fas/Apo-1 mediated apoptosis. Nature 375: 81-83

Martin SJ and Green DR (1995) Protease activation during apoptosis: death by a thousand cuts. Cell 82: 349-352

Muzio M, Chinnaiyan AM, Kischkel FC, O'Rourke K, Shevchenko A, Ni J, Scaffidi C Bretz JD, Zhang M, Gentz R, Mann M, Krammer PH, Peter ME and Dixit VM (1996) FLICE, a novel FADD-homologous ICE/CED-3-like protease, is recruited to the CD95 (Fas/APO-1) death-inducing signaling complex. Cell 85: 817-827

Nagata S and Suda T (1995) Fas and Fas ligand: Ipr and gld mutations. Immunol. Today 16: 39-43

Nicholson DW, Ali A, Thornberry NA, VaillancourtJP, Ding CK, Gallant M, Garceau Y Griffin PR, Labelle M, Lazink YA et al. (1995) Identification and inhibition of the ICE/CED-3 protease necessary for mammalian apoptosis. Nature 376: $37-43$

Obeid LM, Linardic CM, Karolak LA and Hannun YA (1993) Programmed cell death induced by ceramide. Science 259: $1769-1771$

Oehm A, Behrmann I, Weih F, Pawlita M, Maier G, Klas C, LiWM, Richards S, Dhein J, Trauth BC, Ponstingl $\mathrm{H}$ and Krammer PH (1992) Purification and molecular cloning of the APO-1 cell surface antigen, a member of the tumor necrosis factor/ nerve growth factor receptor superfamily: sequence identity with the Fas antigen. J. Biol. Chem. 267: 10709-10715 
Ponton A, Clement MV and Stamenkovic I (1996) The CD95 (Apo-1/Fas) receptor activates NF-kappa B independently of its cytotoxic function. J. Biol. Chem. 271 $8991-8995$

Pronk GJ, Ramer K, Amiri P and Williams LT (1996) Requirement of an ICE-like protease for induction of apoptosis and ceramide generation by REAPER. Science 271: 808-810.

Raff MC (1992) Social controls on cell survival and cell death. Nature 356: 397-400

Sato T, Irie S, Kitada S and Reed JC (1995) FAP-1: a protein tyrosine phosphatase that associates with Fas. Science 268: 411-415

Schlottmann K, Gulbins E, Lau SM and Coggeshall KM (1996) Activation of Srcfamily tyrosine kinases during Fas-induced apoptosis. J. Leuk. Biology 60:546 554

Schütze S, Potthoff K, Machleidt T, Berkovic D, Wiegmann K and Krönke M (1992) TNF activates NF- $\kappa$ B by phosphatidylcholine-specific phospholipase $\mathrm{C}$-induced acidic" sphingomyelin breakdown. Cell 71: 765-776

Singer GG and Abbas AK (1994) The Fas antigen is involved in peripheral but not thymic deletion of T lymphocytes in T cell receptor transgenic mice. Immunity 1 : $365-371$

Smith CA, Farrah T and Goodwin RG (1994) The TNF-receptor superfamily of cellular and viral proteins: activation, costimulation, and death. Cell 76: 959-962

Smith KGC, Strasser A and Vaux DL (1996) CrmA expression in T lymphocytes of transgenic mice inhibits CD95(Fas/APO-1) transduced apoptosis, but does not cause lymphadenopathy or autoimmune disease. EMBO J. 15: 5167-5176

Smyth MJ, Perry DK, Zhang J, Poirier GG, Hannun YA and Obeid LM (1996) prICE: a downstream target for ceramide-induced apoptosis and for the inhibitory acton of Bc12. Biochem. J. 316: 25-28

Stanger BZ, Leder P, Lee T, Kim E and Seed B (1995) A novel protein containing a death domain that interacts with Fas/Apo1 (CD95) in yeast and causes cell death. Cell 81: $513-523$

Stevenson MA, Pollock SS, Coleman CN and Calderwood SK (1994) X-irradiation, phorbol esters and $\mathrm{H}_{2} \mathrm{O}_{2}$ stimulate mitogen activated protein kinase activity in $\mathrm{NIH}-3 \mathrm{~T} 3$ cells through the formation of reactive oxygen intermediates. Cancer Res. 54: $12-15$

Szabo I, Gulbins E, Apfel H, Zhang X, Barth P, Busch AE, Schlottman K, Pongs O and Lang $F$ (1996) Tyrosine phosphorylation dependent suppression of a voltagegated $\mathrm{K}^{+}$channel in T-lymphocytes upon Fas stimulation. J. Biol. Chem. 271: 20465-20469

Takahashi T, Tanaka M, Brannan Cl, Jenkins NA, Copeland NG, Suda T and Nagata S (1994) Generalized lymphoproliferative disease in mice caused by a point mutation in the Fas ligand. Cell 76: 969-976
Tartaglia LA, Ayres TM, Wong GHW and Goeddel DV (1993) A novel domain within the 55 kd TNF receptor signals cell death. Cell 74: 845-853

Tepper CG, Jayadev S, Liu B, Bielawska A, Wolff RA, Yonehara S, Hannun YA and Seldin MF (1995) Role for ceramide as an endogenous mediator of Fas-induced cytotoxicity. Proc. Natl. Acad. Sci. USA 92: 8443-8447

Tewari M and Dixit VM (1995) Fas- and tumor necrosis factor-induced apoptosis is inhibited by the poxvirus CrmA gene product. J. Biol. Chem. 270: 3255-3260

Tewari M, Quan LT, O'Rourke K, Desnoyers S, Zeng Z, Beidler DR, Poirier GG, Salvesen GS and Dixit VM (1995) Yama/CPP32 beta, a mammalian homolog of CED 3, is a CrmA-inhibitable protease that cleaves the death substrate poly(ADP-ribose)-polymerase. Cell 81: 801-809

Tian Q, Taupin J, Elledge S, Robertson M and Anderson P (1995) Fas-activated serine/threonine kinases (FAST) phosphorylates TIA-1 during Fas-mediated apoptosis. J. Exp. Med. 182: 865-874

Trent JC, McConkey DJ, Loughlin SM, Harbison MT, Fernandez A and Ananthaswamy HN (1996) Ras signaling in tumor necrosis factor-induced apoptosis. Embo J. 15: 4497-4905

Verheij M, Bose R, Lin XH, Yao B, Jarvis WD, Grant S, Birrer MJ, Szabo E, Zon LI, Kyriakis JM, Haimovitz-Friedman A, Fuks Z and Kolesnick RN (1996) Requirement for ceramide initiated SAPK/JNK signalling in stress induced apoptosis. Nature 380: $75-79$

Xia Z, Dickens M, Raingaud J, Davis RJ and Greenberg ME (1995) Opposing effects of ERK and JNK-p38 MAP kinases on apoptosis. Science 270: 1326-1331

Watanabe-Fukunaga R, Brannan Cl, Copeland NG, Jenkins NA and Nagata S (1992) Lymphoproliferation disorder in mice explained by defects in Fas antigen that mediates apoptosis. Nature 356: 314-317

WestwickJK, Bielawska AE, Dbaibo G, Hannun YA andBrennerDA (1995) Ceramide activates the stress activated protein kinase. J. Biol. Chem. 270: 22689-22692

Wu J, Zhou T, Zhang J, He J, Gause WC and Mountz JD (1994) Correction of autoimmune disease by early replacement of the mutated Ipr gene with the normal Fas apoptosis gene in the T cells of transgenic MRL-Ipr/lpr mice. Proc. Natl. Acad. Sci. 91: 2344-2348

Wyllie AH, Kerr JFR and Currie AR (1980). Cell death: The significance of apoptosis. Int. Rev. Cytol. 68: 251-306

Zhang J, AlterN, Reed JC, Borner C, Obeid LM and Hannun YA(1996) Bcl2 interrupts the ceramide-mediated pathway of cell death. Proc. Natl. Acad. Sci. USA 93: $5325-5328$

Zhou Q, Snipau S, Orth K, Muzio M, Dixit VM and Salvesen GS (1997) Target protease specificity of the viral serpin CrmA: Analysis of five caspases. J. Biol. Chem. 272: 7797-7800 